\title{
CHÁCARAS DE LAZER: UM ESTUDO SOBRE O ESPAÇO RURAL DE GUARAPUAVA
}

\section{LEISURE FARMSA STUDY ON THE EXPERIENCE OF RURAL SPACE OF GUARAPUAVA (PARANÁ STATE, BRAZIL)}

\author{
Sergio Fajardo \\ Doutor em Geografia \\ UNICENTRO \\ sergiofajardo@hotmail.com \\ Roseli Nychai \\ Mestre em Geografia \\ UNICENTRO \\ rosenichai@ hotmail.com
}

\begin{abstract}
Resumo:
A partir da premissa de que os espaços de Guarapuava-PR estão se transformando no ritmo do desenvolvimento nacional, este artigo deflagra reflexões sócio-espaciais a respeito das vivências nas ruralidades do município, a partir do estudo das chácaras de lazer na condição de domicílio de uso ocasiona. A expansão desse fenômeno é indicativo do desenvolvimento sociocultural e espacial urbano, aliado à modernização do espaço rural. Processo refletido em significativas mudanças no cotidiano tradicionalmente conhecido, principalmente nas relações de produção e trabalho e entre homem e natureza. Os resultados revelaram que o objeto de estudo atrai uma importante parcela da população urbana para as ruralidades do município, além de promover o elemento natural local, moldando uma nova territorialização desse espaço voltado para o lazer e que contribui para o desenvolvimento local.
\end{abstract}

Palavras-chave: atividades não-agrícolas; chácaras de lazer; domicílio de uso ocasional; espaço rural, Guarapuava-PR.

\begin{abstract}
:
Starting from the premise that spaces in Guarapuava (State Of Paraná, Brazil) are becoming the pace of national development, this article triggers socio-spatial reflections on the experiences in ruralities the municipality, from the study of leisure farms in the condition of domicile of use causes. The expansion of this phenomenon is indicative of the socio-cultural development and urban space, coupled with the modernization of the countryside. Process reflected in significant changes in daily life traditionally known, especially in the relations of production and work and between man and nature. The results revealed that the object of study attracts a significant proportion of urban ruralities for the local population, as well as promote local natural element, shaping a new territorialisation of that space dedicated to leisure and contributing to local development.
\end{abstract}

Keywords: non-agricultural activities, leisure farms, occasional home use; rural space; Guarapuava (Paraná State, Brazil). 


\section{INTRODUÇÃO}

Este artigo contempla os resultados da pesquisa defendia em agosto de 2012, no Curso de Mestrado em Geografia, do Programa de Pós-Graduação, área de concentração Dinâmica da Paisagem e dos Espaços Rural e Urbanos, da Universidade Estadual do Centro-Oeste, UNICENTRO.

O objetivo principal desse estudo foi a caracterização das chácaras de lazer na condição de domicílio de uso ocasional, no município de Guarapuava-PR, sua manifestação, dinâmica e as relações que se estabelecem no espaço onde o fenômeno se instala.

A proposta de trabalho foi norteada por uma preocupação em desvendar um fenômeno local que, até então, era vivido pela pesquisadora e não compreendido, levando-se em consideração a seguinte perspectiva: as chácaras de lazer, na condição de domicílio de uso ocasional, instaladas em Guarapuava-PR, influenciam as redes de relações que se estabelecem entre o espaço rural e o urbano?

A abordagem desse fenômeno sobre o enfoque Geográfico apresentar uma realidade local, em especial, no que se refere às suas ruralidades, enquanto lugar de lazer, bem como reflexões a respeito dos citadinos freqüentadores das chácaras de lazer, localizadas no entorno do perímetro urbano do município, bem como das transformações da paisagem local e do uso do solo pelo fenômeno, além de apreender as relações contemporâneas existentes entre o rural e o urbano.

Neste estudo, foram evidenciados que os objetivos propostos foram alcançados, visto que o fenômeno em estudo já se constitui uma realidade no município de Guarapuava-PR, com visível expansão e as análises sobre a organização socio-espacial do objeto de estudo, permitiram levantar um perfil e caracterizar os aspectos socioeconômicos e cultural dos atores sociais envolvidos.

Entre as descobertas, desvendaram-se peculiaridades a respeito das vivências de cada sujeito, o que corrobora na relação entre o rural e o urbano de modo a intensificar cada vez mais as suas singularidades espaciais, bem como contribui para na inter complementaridade desses dois espaços. 
Metodologicamente, a investigação apresenta uma abordagem empírica qualitativa e quantitativa, por meio de uma pesquisa do tipo estudo de caso, com levantamentos de dados secundários e primários.

Foram utilizadas nos dados secundários as informações fornecidas pelos Censos Demográficos dos anos de 2000 e 2010, disponíveis pelo Instituto Brasileiro de Geografia e Estatística, IBGE, bem como levantamentos bibliográficos.

Os dados primários foram inicialmente coletados nos meses de janeiro a março de 2012, por meio da aplicação de um questionário aos citadinos que são proprietários de chácaras de lazer, na condição de domicílio de uso ocasional. Essa estratégia resultou no montante de 89 questionários respondidos e, desses, foram validados para a análise 70 documentos.

Após, buscou-se in locu informações e observações a respeito do fenômeno, por meio de visitas realizadas durante o mês de abril de 2012, às propriedades objeto de estudo, localizadas nos distritos administrativos de Guarapuava - PR. Foram entrevistadas nessas visitas 21 pessoas, sendo sete proprietários de chácaras de lazer; cinco caseiros/funcionários; três esposas de caseiros que residem na propriedade e seis moradores vizinhos dessas propriedades.

Destaca-se que, os agentes respondentes para comporem a amostra da pesquisa foram selecionados pelo critério da intencionalidade não-probabilística, considerando a possibilidade da escolha e conveniência do pesquisador, subordinados ao objetivo proposto pela pesquisa (SAMARA; BARROS, 1997), e as chácaras de lazer visitadas foram selecionadas a partir das respostas apresentadas no questionário aplicado aos citadinos proprietários.

Essas ações objetivaram caracterizar os atores envolvidos e como eles se relacionam com o objeto de estudo, com o espaço local e a sociedade (SANTOS, 1985, p. 1).

Para conhecer as ações e reflexões públicas acerca da temática, optou-se em buscar informações junto ao Poder Público Municipal, por meio das Secretarias de Habitação, da Agricultura e do Turismo.

Os instrumentos aplicados na fase exploratória, juntamente com o referencial teórico- conceitual, sob uma abordagem de cunho qualitativo, possibilitaram o conhecimento sobre o objeto de estudo, legitimando-o para o estudo de caso, tendo em 
vista que, a legitimação é dada a partir do estudo minucioso, por meio da caracterização, conceituação e classificação do fenômeno, a partir dos conhecimentos produzidos anteriormente (SPOSITO, 2004).

Entretanto, importante destacar que este trabalho exigiu exaustivo esforço em catalogar informações a respeito do objeto de estudo, considerando:

a) limitações decorrentes do receio, por parte dos proprietários das chácaras de lazer e entrevistados, de fornecer informações sobre o imóvel pesquisado; e

b) falta de registro e de consenso das bases de informações públicas a respeito da temática.

\section{AS VIVÊNCIAS NA SOCIEDADE CONTEMPORÂNEA, NO CONTEXTO DAS RURALIDADES}

O modo de utilização das ruralidades indica a evolução da sociedade, aliada às atividades produtivas que estão associadas à demanda do fenômeno em estudo, valorizado pelo elemento natural que norteia esse tipo de domicílio, além de moldar uma nova territorialização desse espaço.

O fenômeno das chácaras de lazer na condição de domicílio de uso ocasional é um bônus, resultante da dinâmica da sociedade contemporânea, moldada de acordo com o comportamento do homem que recria os espaços de vida e estes se configuram como territórios de expressão da vivência, lapidados com as especificidades de cada lugar.

As vivências e as relações estabelecidas na sociedade contemporânea são definidas pelas mudanças promovidas pela humanidade e dinamizadas, principalmente, pelo desenvolvimento das comunicações e dos transportes. Esses fatores permitiram a unificação de distantes lugares do globo e a liberdade criadora para o homem moldar o seu uso do solo. Desse modo, o domicílio pode ser construído no lugar que o homem almejar, de acordo com os seus adjetivos peculiares.

A mudanças também ocorrem cultural e socialmente, possibilitando um intenso fluxo de pessoas, bens e serviços, resultando na melhoria do tempo e da qualidade de vida, além de contribuir para a ressignificação do espaço geográfico como um bem de uso. 
Destaca-se que a sociedade contemporânea alimenta inúmeras contradições em meio a uma realidade virtual, com profundas transformações dos valores sociais tradicionalmente construídos. Valores que são substituídos, transformados, recambiados e transmutados pelos efeitos das carências e inquietações da rotina contemporânea.

Nessa sociedade, os valores financeiros são substituídos por bens imobiliários, e que a família está configurada por meio de uma recomposição genealógica, incorporando domicílios com endereço plural, pulverizado em diferentes cidades e também entre o campo e a cidade.

As transformações concebidas pelo desenvolvimento desencadearam uma pressão social contínua, mas também possibilita à sociedade contemporânea usufruir da mobilidade espacial como forma de aliviar as tensões do dia-a-dia. Esse processo está respaldado pelas mudanças socioeconômicas e no modo de viver da sociedade, em que a maximização da produtividade resultou no aumento do tempo do não-trabalho e possibilitou às pessoas aproveitar novas formas de lazer e recreação nesse tempo.

O homem moderno vive em grandes cidades, congestionadas, barulhentas e opressivas, provocando a necessidade de procurar novos espaços mais libertos e calmos onde se possa descansar e encontrar ar puro e liberdade de circulação. Este progresso deve-se também a uma alteração da estrutura social, melhorias econômicas de motorização e de acessibilidades, bem como o alargamento dos tempos livres (WILDE, 1968 apud CALDEIRA, 1995, p. 4).

Dessa forma, a sociedade está cada vez mais buscando outras vivências, mesmo que temporariamente, para poder recuperar sua vitalidade. É comum pessoas procurarem paisagens diferentes das vivenciadas nos centros urbanos para usufruírem no tempo do não-trabalho.

Muitos estudos foram feitos sobre as carências que provocam a migração da área rural para os centros urbanos e sobre o fascínio que a cidade exerce ao responder às grandes necessidade humanas como trabalho, educação, saúde, cultura, lazer etc. Porém, pouco se interroga sobre o encantamento que o universo rural exerce sobre as populações urbanas [...] (SILVA, 2009, p. 1-2).

Os novos espaços que o homem moderno busca são, normalmente, encontrado nas paisagens com características e encantamento do universo rural, capaz de aguçar a imaginação de uma vivência melhor junto a essa paisagem, com a natureza em volta e

Geo UERJ - Ano 15, nº. 24, v. 2, $2^{\circ}$ semestre de 2013

ISSN: 1415-7543E-ISSN: 1981-9021

http://www.e-publicacoes.uerj.br/index.php/geouerj 
com mais qualidade de vida, fora do modelo urbano.

\begin{abstract}
Novos valores sustentam a procura da proximidade com a natureza e com a vida no campo. A sociedade fundada na aceleração do ritmo da industrialização passa a ser questionada pela degradação das condições de vida dos grandes centros. O contato com a natureza é, então, realçado por um sistema de valores alternativos, neo-ruralista e antiprodutivista. $\mathrm{O}$ ar puro, a simplicidade da vida e a natureza são vistos como elementos "purificadores" do corpo e do espírito poluídos pela sociedade industrial. O campo passa a ser reconhecido como espaço de lazer ou mesmo como opção de residência (CARNEIRO, 1998, p. 55).
\end{abstract}

Concordamos com essa autora, que ressalta que as transformações dos espaços são decorrentes das demandas da atual sociedade e destaca que a procura crescente de novas formas de lazer e até mesmo de meios alternativos de vida no campo, está engajado nas multifuncionalidades do rural e nas possibilidades de pluriatividades para a população rural, até então dedicada quase exclusivamente à agricultura.

Segundo Almeida (2003, p. 457), a multifuncionalidade do rural é uma "forma de conceber o desenvolvimento rural que passa de uma visão setorial para um visão integrada, coletiva e com ligações com outros setores da sociedade", e a pluriatividade do rural, de acordo com Scheneider (2003, p. 79), referencia “o processo de diversificação que ocorre dentro e fora da propriedade, bem como para apontar a emergência de um conjunto de novas atividades que tomam lugar no meio rural", ou seja, refere-se a diversificação das atividades não-agrícolas e das fontes de renda das famílias que residem no campo.

Assim, pode-se entender que o espaço rural apresenta funções e atividades multi plurias, associado às modernas atividades não agrícolas em meio ao tradicional e principal papel de produtor de alimentos e matérias-primas, abrindo um leque de possibilidades para esse espaço e para seus agentes sociais. Essa nova roupagem permite a diversificação das atividades não-agrícolas e das fontes de renda às famílias que residem no campo.

Esse espaço concebido também como lazer representa um importante marco decorrente das mudanças da sociedade e se mostra como um elo nas relações campo cidade, que promovem ações recíprocas entre o campo e a cidade, tendo em vista a mobilidade espacial e as constantes interações desses dois espaços. Eles deixam de ser heterogêneos e passam a ser interdependentes, entretanto singulares, por apresentarem

Geo UERJ - Ano 15, nº. 24, v. 2, $2^{\circ}$ semestre de 2013

ISSN: 1415-7543E-ISSN: 1981-9021

http://www.e-publicacoes.uerj.br/index.php/geouerj 
diferentes qualidades que se contrapõem e se complementam para o equilíbrio da vida.

Destaca-se que esse espaço - que era então conhecido apenas como rural agropecuário - apresenta-se hoje com uma roupagem valorizada pela capacidade de partilhar sua função de produtor de alimentos com um espaço com inúmeras responsabilidades e, entre elas, a premissa enquanto espaço de lazer, propiciando uma vida mais agradável e saudável.

Destaca-se que a nova territorialização assume o perfil identificado por Haesbaert (2006), como sendo a apropriação pelo homem do espaço social por meio do uso de algum tipo de poder dominante, considerando que o espaço abordado nesta pesquisa está estreitamente vinculado às ideias do racionalismo. Dessa forma, a relação do homem com a natureza deixa de ocorrer apenas pelo seu valor de uso e passa, com a prática do capitalismo, a ser considerado também como recurso, agregando um valor de troca, em que "[...] a natureza (abstrata) e seus elementos são mercantilizados, seja indiretamente (ideia de reencantamento da natureza, apropriada pela atividade turística) ou diretamente (através da comercialização das riquezas naturais)" (MOREIRA SCHNEIDER, 2009, p. 72).

Ademais, essa territorialização é marcada por profundas mudanças de ordem existencial do homem contemporâneo, principalmente na relação do tempo de trabalho com o tempo do não-trabalho. Isso ocorre em função da demanda globalizada e da transitoriedade das relações, que forjam novas propostas para o tempo das pessoas e possibilidades de diferentes formas de convivência sociais. Tal perspectiva promove a descaracterização da "[...] relação que o homem estabelece com as coisas, com seus semelhantes, com as instituições, com seus próprios valores e consigo mesmo" (BENI, 2004, p. 76).

Nesse entendimento, desvenda-se uma realidade local que contempla um espaço contemporâneo com crescente urbanização e com um considerável aumento de atividades rurais não-agrícolas, aliada às multifuncionalidades, que interagem na organização sócio-espacial do município de Guarapuava-PR.

Nessa abordagem é importante compreender a amplitude da manifestação das chácaras de lazer em Guarapuava-PR, cujo fenômeno também é referenciado na literatura como domicílio de uso ocasional, residência secundária ou segunda residência, sítios de lazer ou recreio, que se manifesta e é caracterizado de forma diferenciada em 
cada lugar que se instala.

Segundo Assis (2003), o fenômeno recebe diferentes enfoques de estudo por ser um evento complexo e ainda necessita de um consenso terminológico a fim da construção de um conceito amplo, capaz de envolver uma variedade de aspectos, tais como: "[...] o deslocamento de pessoas, ocupação de domicílios de forma não permanente, geração de oportunidades e ampliação da infra-estrutura, dentre outros, vindo a, inclusive, ocasionar mudanças substanciais quando de sua instalação" (WANDSCHEER; LINDNER; SOUZA, 2011, p. 36).

A proclamação de uma definição consensual é uma tarefa difícil, considerando diferentes fatores e aspectos, decorrente do universo de possibilidades de diferentes espaços e paisagens que podem se instalar.

\begin{abstract}
Os problemas começam pelo facto das residências secundárias não constituírem um tipo discreto: caravanas, traillers, houseboats, são ou não, consideradas como residência secundária, já que tem a mesma função? O regime de propriedade, se é própria ou alugada, levanta também alguma controvérsia, havendo quem defenda uma definição mais lata e considere todas, enquanto outros contemplam apenas as que são próprias. $\mathrm{O}$ tipo de actividade desenvolvida nestes alojamentos é outra das características passíveis de levantar algumas questões, uma vez que estas casas se destinam essencialmente ao descanso e lazer, o facto de aí se desenvolverem actividades profissionais permite ou não continuar a classificá-las como residência secundária? E, nos últimos tempos, até a frequência de utilização é introduzida como factor distintivo entre residências secundárias e residências de férias (CALDEIRA, 1995, p. 17).
\end{abstract}

Essa autora evidencia algumas preocupações com relação a definição universal de um termo ou tipologia para o fenômeno em estudo, que geraria muitas controvérsias, por sua multidisciplinaridade e diferentes interpretações, bem como devido a suas múltiplas relações econômicas, sociais, políticas e cultural que vêm se difundindo no mundo contemporâneo de forma acelerada.

Mesmo o fenômeno apresentando várias classificações, com diferentes termos, Tulik (2001, p. 11), caracteriza o objeto de estudo como “[...] propriedades particulares utilizadas temporariamente, nos períodos de tempo livre, por pessoas que têm sua residência permanente em outro lugar".

Destaca-se que o fenômeno em tela está incorporado em um espaço plural que, 
além de privilegiar atividades agrícolas, contempla também outras destinadas ao lazer, à recreação e ao ócio, integrando-se com um possível contingente para a oferta de emprego às famílias de agricultores, além de agregar valor ao lugar.

Dessa forma, nesta pesquisa é editada uma nomenclatura e terminologia própria que representa o objeto de estudo e conjuga a materialização do pensamento pretendido, considerando que é um tipo de hospedagem particular, especificamente, localizada nos espaços com características rurais, no município de Guarapuava, caracterizada pela finalidade de promover o lazer da família nos finais de semanas e demais períodos do não-trabalho.

No caminho para a classificação do fenômeno, instituí-se a expressão "chácara de lazer", seguida da complementação "na condição de domicílio de uso ocasional”, que passa a ser definida como sendo: imóvel particular rural, que não contempla lucro, cuja propriedade pode ser permanente ou provisória, que serve ocasionalmente de domicílio ao citadino que possui sua residência principal em outro local, e que busca alguma qualidade ambiental e paisagística nas ruralidades locais, para descanso e lazer nos fins de semana, férias e tempo livre.

Necessário se faz esclarecer que a palavra "chácara" é um termo comum na região e de crescente uso devido à chegada de pessoas da cidade nas áreas rurais (BRANDÃO, 1995), e que representa o objeto de estudo desta pesquisa, considerando que:

Sítio é o espaço onde vivem e trabalham os moradores [...] e chácara é o lugar frequentado por pessoas vindas da cidade, geralmente nos finais de semana. Ambas são categorias nativas utilizadas tanto pelos sitiantes, como pelos "chacareiros". [...] Já a chácara pode ser entendida como um lugar secundário na identidade do indivíduo, ela é um anexo, um complemento da vida do chacareiro que a utiliza para o lazer, sendo que a produção que ocorre nas chácaras acontece com o objetivo de proporcionar um "descanso mental" (BERNARDES, 2005, p. 22).

E, ainda, de acordo com o Dicionário Houaiss da Língua Portuguesa (HOUAISS; VILLA, 2001, p. 684 - grifo nosso), a palavra “chácara” significa: “1. propriedade rural voltada para a avicultura, a pequena criação de animais, o plantio de frutas, legumes etc. 2. pequena propriedade campestre, freq. destinada ao lazer; casa de campo; 3. grande propriedade urbana, com habitação e área verde"; e, conforme

Geo UERJ - Ano 15, no . 24, v. 2, $2^{\circ}$ semestre de 2013

ISSN: 1415-7543E-ISSN: 1981-9021

http://www.e-publicacoes.uerj.br/index.php/geouerj 
o Moderno Dicionário da Língua Portuguesa Micaelis (1990): 1- Pequena propriedade agrícola nas cercanias de cidades para uma ou mais das seguintes atividades: cultivo de verduras e legumes, cultivo de árvores frutíferas, fabricação de laticínios, criação em pequena escala etc. 2 Casa de campo perto da cidade.".

Quanto à adoção do termo "lazer", considera-se que ele caracteriza a finalidade principal dessa propriedade, além de identificar seu vínculo com a demanda tipicamente contemporânea de criar relações com o tempo do trabalho e do não-trabalho, característico do período pós-industrial (MARCELLINO, 1990). Segundo o Dicionário Houaiss da Língua Portuguesa (HOUAISS; VILLA, 2001, p. 1733), o termo "lazer" significa: “1. tempo que sobra do horário de trabalho e/ou do cumprimento de obrigações, aproveitável para o exercício de atividades prazerosas. 2. atividade que se pratica nesse tempo; 3. cessação de uma atividade; descanso, repouso; (grifo nosso)"

Ericsson (2006) respalda a utilização do termo "lazer", defendendo que a denominação do fenômeno deve derivar do conceito de recreação e lazer como um dos motivos mais importantes, bem como a atividade que deve estar relacionada a estas casas e também se contrapondo aos turistas que visitam apenas uma ou outra vez aquele local. Assim, segundo esse autor, os usuários dos domicílios de recreio ou lazer são caracterizados pela recorrência e pelo frequente investimento privado em um determinado lugar ou localidade.

Ademais, para garantir que a "chácara de lazer" não corresponde à residência principal, busca-se reforço na definição técnica utilizada pelo IBGE, que categoriza o fenômeno, com a variável "domicílio de uso ocasional", que corresponde ao "domicílio particular permanente que serve ocasionalmente de moradia de pessoas que possui sua residência principal em outro local e que são usadas para descanso de fins de semana, férias ou outro fim" (IBGE, 2010).

Assim, utilizou-se nesta pesquisa a classificação adotada pelo IBGE, conforme segue:

I) Categoria: domicílios não-ocupados;

II) Variáveis:

a) domicílios de uso ocasional e;

b) domicílios vagos/fechados.

Segundo Gomes (2008), a variável “domicílios de uso ocasional” é um indicador 
para a investigação do fenômeno da chácara de lazer e a variável "domicílios vagos/fechados" permite sinalizar uma possível potencialidade para a efetivação do fenômeno pesquisado.

A rotina das pessoas na dinâmica urbana desencadeia a procura por um lazer diferenciado, que concilie obrigações sociais e profissionais urbanas com um tempo livre, em meio a um tranquilo lugar. A busca desse lugar direciona para uma paisagem com características naturais, promovendo uma demanda por esses espaços.

Trata-se de um fenômeno sócio-espacial característico da sociedade contemporânea que privilegia a prática do lazer em seu tempo de não-trabalho por meio da hospedagem em domicílios de uso ocasional.

No Brasil, este nicho de lazer está associado às famílias da classe média, que dispensam a estadia em hotéis, por ser mais oneroso, considerando o número de membros da famílias e o tempo de hospedagem. Isso tendo em vista que a classe de renda alta está mais propensa às viagens internacionais e a frequentar os resorts localizados em diferentes paisagens brasileiras.

Segundo Rodrigues (apud GARCIA, 2007, p. 45), as pessoas citadinas estão motivadas a optarem por esse tipo de lazer, que consideram:

Uma mudança de ambiente, um tipo de vida diferente que lhes permita a recuperação de energias perdidas; - um contato mais próximo com a natureza, na alimentação do mito do eterno retorno; - uma vivência com pessoas cujos modos de vida são tidos como simples, em oposição aos padrões comportamentais urbanos, considerados frios e despersonalizados; - um lugar não massificado, diferenciado, bucólico, tranquilo, sem ruídos; - algo considerado autêntico e natural.

As características essenciais da urbanização contemporânea, diante da velocidade e generalização, chegam a um ponto de estrangulamento dos sistemas de produção, enquanto as necessidades de consumo passam por intensa vitalização, o que leva a incluir o consumo por novos espaços e novos estilos de vida.

Segundo Assis (2003), o processo urbano está configurado numa trajetória constante da busca de novos espaços com amenidades sociais e ambientais, com potencialidades para a prática do lazer. Desse processo decorrem as mudanças do modo de vida da população, dos hábitos e dos costumes que exigem uma ampliação da capacidade e qualidade dos bens e serviços públicos a serem aprimorados no processo 
de produção das cidades do porte de Guarapuava.

Esse processo de estruturação e de desenvolvimento é sentido tanto no espaço rural como no urbano de Guarapuava, que são reflexos das novas demandas de uma sociedade pós-industrial.

Assim, a sociedade contemporânea busca o bem-estar e o reequilíbrio da vida, produzindo novos espaços e novas práticas sociais em locais com ambiente propício para as práticas de lazer junto à família.

Dessa forma, são caracterizadas as separações físicas das obrigações quotidianas com o lazer e o descanso, influenciando no comportamento e nas relações das pessoas com o meio físico e social, cujas relações entre o espaço rural e o urbano interligam-se cada vez mais em um conjunto de processos e "[...] circunstâncias dinâmicas, nomeadamente do âmbito social, cultural, econômico e bio-psicológico" (SAMPAIO, 2000, p. 140).

Essa é uma realidade vivenciada pela população que reside e trabalha no meio urbano de Guarapuava, que também está descobrindo os prazeres nas ruralidades do município.

\section{A CONFIGURAÇÃO DO ESPAÇO DE GUARAPUAVA - PR NAS RURALIDADES DAS CHÁCARAS DE LAZER}

Guarapuava está situada na região Centro-Sul do Estado do Paraná e apresenta uma paisagem diversificada nos seus $3.116,313 \mathrm{Km}^{2}$ de extensão territorial, que dispõe de belezas e atrativos peculiares, que comportam as chácaras de lazer, cujo fenômeno é um fator importante de transformação da paisagem e do uso do solo.

Destaca-se que nessa paisagem é observada “[...] tudo aquilo que nós vemos, o que nossa visão alcança, [...] aquilo que a vista abarca. Não é formada apenas de volumes, mas também de cores, movimentos, odores, sons etc" (SANTOS, 1997, p. 61), que resultam em "[...] um conjunto de formas que, num dado momento, exprime as heranças que representam as sucessivas relações localizadas entre homem e natureza" (SANTOS, 2002, p. 103).

A paisagem, além de ser o resultado de elementos bióticos e abióticos e das grandes influências das atividades humanas, apresenta-se também com intervenções 
econômicas, que promovem a sua metamorfose, produzindo novas configurações territoriais (FAJARDO, 2008).

Dessa forma, essa paisagem incorpora uma população estimada de 167.463 habitantes (IBGE, 2010), sendo que mais de 90\% da população está hoje concentrada na área urbana, distribuídas entre o distrito sede e mais cinco outros que integram os domínios territoriais do município.

A organização sócio-espacial urbana de Guarapuava teve um processo gradual se comparado com demais municípios do estado do Paraná. De acordo com o Gráfico 1, somente a partir da década de 1980 a população urbana tornou-se maior do que a rural e Guarapuava passou a ser considerada como pólo regional de desenvolvimento, com forte influência dentro da complexa rede de cidades vizinhas.

\section{Gráfico 1 - Evolução da população em Guarapuava - 1970/2010}

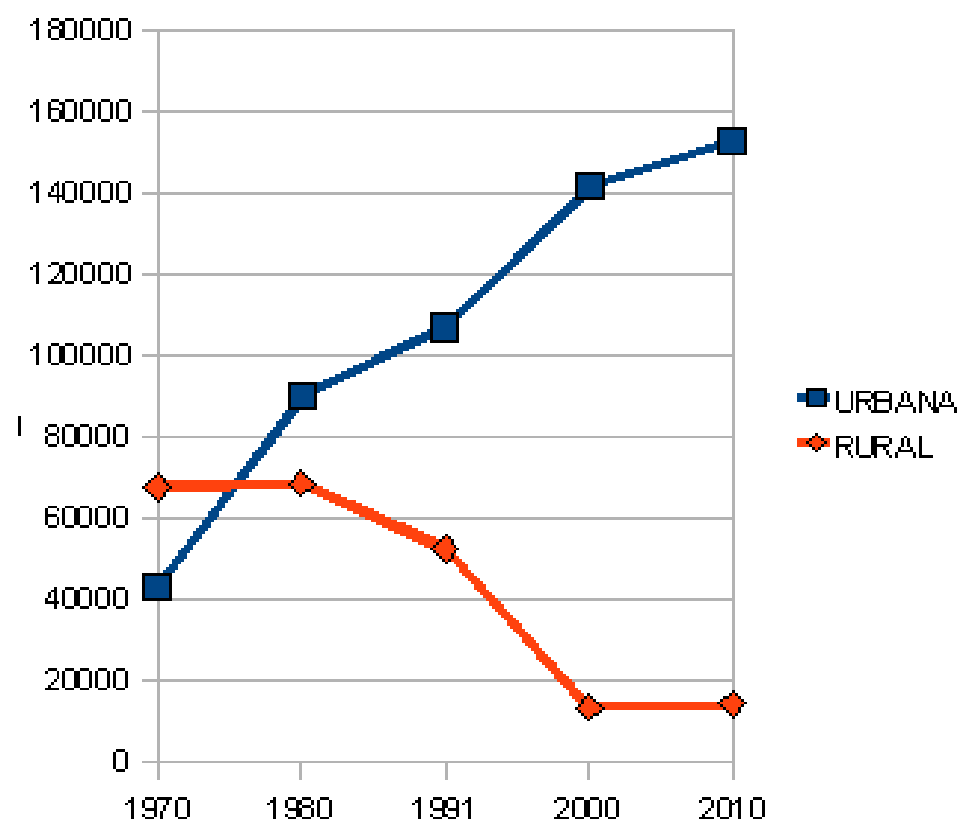

Fonte IBGE - Censos Demográficos (1970, 1980, 1991, 2000 e 2010).

Org.: a autora.

Historicamente, a população urbana de Guarapuava, no período de 1970 a 2010, teve uma expansão superior a $250 \%$, certificando que o “[...] município passou por um processo contínuo de aumento da população total [...], superando a evolução do total da 
população do estado do Paraná" (SCHMIDT; LOBODA, 2011, p. 26).

Destaca-se que, no período de 1991/2010, o município teve um aumento de $4,8 \%$ no número de habitantes e uma taxa de urbanização de $2,29 \%$, apresentando equivalência ao crescimento da população estadual (IPARDES, 2010).

Entretanto, verifica-se que a população do espaço rural não reduziu, ao contrário, houve um crescimento de $0,63 \%$, visto que, no período de 2000 a 2010, foi registrado um aumento de aproximadamente $6,5 \%$ da população rural (IPARDES, 2011), promovendo dessa forma transformação espacial e econômica no cotidiano dos espaços rurais e urbanos que se complementam e apresentam interdependências de suas funções.

Destaca-se que o processo de evolução da urbanização do município foi decorrente, principalmente, da evasão populacional dos municípios vizinhos de Guarapuava que apresentavam um grau de urbanização muito baixo, não possuindo capacidade para garantir sua sustentação, além de um elevado volume de população rural (SCHMIDT; LOBODA, 2011).

Aliado a esse processo também merece destaque o processo a expansão dos cursos superiores de graduação ofertados pelas universidades públicas, estadual e federal, e faculdades particulares. Esses cursos difundiram-se e influenciaram nas mudanças da estrutura populacional e o modo de vida da população de Guarapuava, em decorrência da dinâmica que se estabelece com a circulação de pessoas, promovendo econômica e socialmente o relacionamento de atividades comerciais e de serviços.

Para a compreensão do ambiente sociocultural, destaca-se o enfoque das manifestações sociais e dos costumes locais, respaldado nos acontecimentos gerados com o processo da evolução dos modelos agrícolas nacionais, que refletiram nos avanços das tecnologias agrícolas e da produção, com a monocultura de soja, trigo e milho, bem como na ampliação das áreas de pastagens.

Segundo Silva (1997), esse processo foi registrado em âmbito estadual e de forma similar no município de Guarapuava, mesmo que tardiamente, considerando os fortes estímulos de preço e retorno à produção em alta escala, aliados à intensificação do processo de industrialização, processos que resultaram em uma mudança radical nas bases econômicas da sociedade local, que até então estavam vinculadas ao tropeirismo, extração e transformação da madeira e erva-mate. 
O processo de modernização agrícola também desencadeou o desenvolvimento do processo urbano industrial, transformando os espaços rural e urbano, promovendo novas relações econômicas e espaciais entre o campo e a cidade.

Relações dinâmicas que refletiram nos modos de vida dos habitantes desses espaços, decorrente, ainda que indiretamente, do processo de transformação do espaço geográfico brasileiro que incorporou a ciência, a tecnologia e a informação nas suas relações de produção, de trabalho e de consumo.

Entretanto, segundo Ferreira (2010, p. 197), “[...] mesmo apresentando população urbana maior que a rural, Guarapuava ainda conserva características culturais vinculadas ao campo que se mesclam às atividades e ao modo de vida urbano".

Dessa forma, os espaços periféricos da área urbana, assim como os distritos rurais, passam a ser as principais áreas para a instalação das chácaras de lazer, na condição do domicílio de uso ocasional, cujas ruralidades são valorizadas diante de seus atributos naturais e culturais, convertendo-se num fato sociocultural característico da sociedade contemporânea.

A TABELA A apresenta a expansão dos domicílios no município de Guarapuava - PR, no período de 1991 a 2010.

TABELA A - Número de domicílios segundo uso/tipo - 1991/2000/2010 Guarapuava

\begin{tabular}{|l|r|r|r|r|r|r|r|r|r|r|}
\hline & \multicolumn{3}{|c|}{ URBANO } & \multicolumn{3}{|c|}{ RURAL } & \multicolumn{3}{c|}{ TOTAL } \\
\hline & $\mathbf{1 9 9 1}$ & $\mathbf{2 0 0 0}$ & $\mathbf{2 0 1 0}$ & $\mathbf{1 9 9 1}$ & $\mathbf{2 0 0 0}$ & $\mathbf{2 0 1 0}$ & $\mathbf{1 9 9 1}$ & $\mathbf{2 0 0 0}$ & $\mathbf{2 0 1 0}$ \\
\hline I - Coletivos & 57 & 43 & 56 & 27 & 1 & 9 & 87 & 44 & 65 \\
\hline II - Particulares & 30.486 & 43.122 & 52.027 & 11.250 & 4.417 & 5.644 & 41.709 & 47.539 & 57.671 \\
\hline 2.1 Ocupados & 28.860 & 38.635 & 46.399 & 10.047 & 3.549 & 4.270 & 38.907 & 42.184 & 50.669 \\
\hline 2.2 Não ocupados & 1.626 & 4.487 & 5.628 & 1.176 & 868 & 1.374 & 2.802 & 5.355 & 7.002 \\
\hline 2.2.1 De uso ocasional & 170 & 587 & 1.378 & 338 & 407 & 689 & 508 & 994 & 2.067 \\
\hline 2.2.2 Vagos/fechados & 1.456 & 3.900 & 4.250 & 838 & 461 & 685 & 2.294 & 4.361 & 4.935 \\
\hline TOTAL DE & & & & & & & & & & \\
\hline
\end{tabular}

Fonte: Sinopse preliminar dos censos demográficos de 1991, 2000 e 2010. 
Org.: a autora.

Com destaque para a categoria dos domicílios não ocupados, os números apresentados nessa tabela demonstram um crescimento considerável no número de domicílios de uso ocasional em Guarapuava, que passou de 508 domicílios em 1991 para 2.067 ocorrências em 2010, representando uma expansão de 307\%.

Verifica-se que, dos 399 municípios paranaenses recenseados pelo IBGE em 2010, Guarapuava está em $10^{\circ}$ lugar no ranking em valores absolutos (rural e urbano) no número de domicílio de uso ocasional e perde posição para as cidades litorâneas (Matinhos, Pontal do Paraná e Guaratuba), onde existe um considerável número de casas de veraneio ou de praia, também identificadas como domicílio de uso ocasional; para a capital do estado (Curitiba); e para os centros urbanos do Estado (Londrina, Ponta Grossa, Maringá, Cascavel e São José dos Pinhais).

Observa-se também que na variável de domicílios vagos/fechados é diagnosticada uma reserva técnica do objeto de estudo, com o registro de 4.935 propriedades em Guarapuava, que podem se transformar em possíveis domicílios de uso ocasional no espaço do município (área rural e urbana).

Nessa dimensão, com base nas variáveis em estudo, pode-se concordar que as chácaras de lazer como domicílio de uso ocasional, estão diretamente relacionadas à expansão urbana e urbanização dos municípios e tendem a ocorrer em áreas próximas a centros regionais, já que o fenômeno possui uma maior presença nas áreas metropolitanas, seguidas pelas cidades de porte médio, a exemplo de Guarapuava (FERREIRA, 2011).

Ademais, acredita-se que a organização espacial desses imóveis está relacionada ao desenvolvimento socioeconômico existente no local onde o fenômeno se instala, considerando seu potencial socioeconômico, tendo em vista as interações em razão das populações formada por pessoas com diferentes interesses, filosofias, ocupações e posições de classe sociais (ANSARAH, 1993).

Uma situação que merece ser destacada está no fato de que nos anos de 1990 e 1996 o município de Guarapuava sofreu os desmembramentos ${ }^{1}$ dos municípios de

1 Segundo Schmidt (2009, p. 99), foi a partir de 1877, que teve "[...] início o processo de constituição de novos municípios a partir da área de Guarapuava. Nesse ano, ocorreu o desmembramento de Palmas. Em 1906, constitui-se o município de Prudentópolis, em 1914, o município de Foz do Iguaçu;

Geo UERJ - Ano 15, nº. 24, v. 2, $2^{\circ}$ semestre de 2013

ISSN: 1415-7543E-ISSN: 1981-9021

http://www.e-publicacoes.uerj.br/index.php/geouerj 
Candói e de Campina do Simão e, mesmo assim, o fenômeno em estudo continuou crescendo acentuadamente, com mas de $300 \%$ na contagem geral para o município no período de 1991 a 2010.

A TABELA B ratifica a grande expansão das chácaras de lazer, identificadas por meio da variável domicílio de uso ocasional, distribuídos entre os distritos administrativos do município de Guarapuava.

TABELA B - Domicílios de uso ocasional recenseados por distrito - GuarapuavaPR

\begin{tabular}{|l|c|c|c|c|c|c|c|}
\hline & \multicolumn{2}{|c|}{ URBANO } & \multicolumn{4}{c|}{ RURAL } & \multicolumn{2}{c|}{ TOTAL } \\
\hline \begin{tabular}{l} 
DOMICÍLIOS P/ \\
\multicolumn{1}{c|}{ DISTRITO }
\end{tabular} & $\mathbf{2 0 0 0}$ & $\mathbf{2 0 1 0}$ & $\mathbf{2 0 0 0}$ & $\mathbf{2 0 1 0}$ & $\begin{array}{c}\text { Expansão } \\
\mathbf{2 0 0 0 / 2 0 0 1}\end{array}$ & $\mathbf{2 0 0 0}$ & $\mathbf{2 0 1 0}$ \\
\hline Sede & & & & & & & \\
\hline Atalaia & 545 & 1309 & 183 & 283 & $54,65 \%$ & 728 & 1592 \\
\hline Entre Rios & - & - & 13 & 28 & $115,00 \%$ & 13 & 28 \\
\hline Guairacá & 28 & 42 & 93 & 126 & $35,50 \%$ & 121 & 168 \\
\hline Guará & 3 & 4 & 57 & 85 & $49,20 \%$ & 60 & 89 \\
\hline Palmeirinha & 8 & 6 & 30 & 123 & $310,00 \%$ & 33 & 129 \\
\hline TOTAL & $\mathbf{5 8 7}$ & $\mathbf{1 3 7 8}$ & 31 & 44 & $42,00 \%$ & 39 & 61 \\
\hline
\end{tabular}

Fonte: Sinopse preliminar do censo demográfico 2000 e 2010

Org.: A autora.

$\mathrm{Na}$ classificação do IBGE o rural ou o espaço com características de rural, também é encontrado no perímetro urbano, ou seja, na sede do município.

Nesse entendimento, no espaço rural, o distrito do Guará registrou maior incidência do fenômeno em estudo, com um crescimento de $310 \%$ em dez anos (2000/2010), seguido pelo distrito de Atalaia, com um incremento de 115\%, nesse mesmo período.

Importante crescimento do fenômeno também ocorreu no distrito sede (que apresenta ruralidades), com 54,65\% no período de 2000/2010. Essa expansão se

em 1943, o município de Laranjeiras do Sul que se torna a capital do Território do Iguaçu de 1943 a 1946; em 1943, o município de Pitanga; em 1944, Campo Mourão; em 1960, o município de Inácio Martins; em 1961, o município de Palmital; em 1964, o município de Pinhão; em 1980, o município do Turvo; em 1982, o município de Cantagalo, em 1990, o município de Candói; em 1996, o município de Campina do Simão.” 
justifica em decorrência da grande extensão do perímetro urbano do município, que traz características rurais, a exemplo do Vale do Jordão e os limites do bairro Santana.

\section{TABELA C - Distribuição da localização das chácaras de lazer segundo a finalidade de uso - Guarapuava}

\begin{tabular}{|l|c|c|c|c|}
\hline \multicolumn{5}{|c|}{ FINALIDADE DO USO } \\
\hline \\
\hline
\end{tabular}

Fonte: Pesquisa de Campo (2012).

Org.: a autora.

Os dados e observações coletadas na faze exploratória da pesquisa foram tabulados e a localização e finalidade de uso do objeto de estudo é apresentado na TABELA C, permitindo arrazoar a caracterização das chácaras de lazer na condição domicílio de uso ocasional, localizadas nas ruralidades de Guarapuava.

Foi incorporada a variável "finalidade do uso da chácara de lazer" para identificar o perfil das propriedades incluídas na amostragem, de forma a representar o objeto de estudo.

A TABELA C representa o universo pesquisado e permitiu observar que cerca de $51,68 \%$ das chácaras de lazer foram adquiridas desde o início para essa função, enquanto $38,20 \%$ são propriedades herdadas de parentes, transformadas em chácaras de lazer.

Entretanto, nove citadinos inquiridos - todos do distrito sede - responderam que possuem chácara de lazer na condição de domicílio principal, representando 10,11\% da amostragem. Essas propriedades estão localizadas no Bairro do Jordão, com 6 registros, 
e no Bairro Santana, com 3 registros, tendo em vista que os limites ou prologamentos dessas localidades são empiricamente caracterizados como áreas rurais.

Verifica-se com esse resultado que o fenômeno também está instalado no distrito sede, cujo espaço apresenta novas ruralidades que se incorporam na paisagem do município.

Constata-se também que $11,23 \%$ dos proprietários respondentes possuem chácara de lazer em outros municípios vizinhos a Guarapuava (Pinhão: dois proprietários; Santa Maria do Oeste: um proprietário; Turvo: três proprietários; Prudentópolis: um proprietário; Inácio Martins: um proprietário; e Candói: dois proprietários).

Diante desse diagnóstico, foram descartados os questionários respondidos por citadinos que possuem a "chácara de lazer como domicílio principal" e aqueles que possuem "chácara de lazer em outros municípios" por não representarem, diretamente, o objeto de estudo.

Porém, esse percentual pode ser um bom indicativo da tendência do guarapuavano, que acompanha a tendência global e transforma a então chácara de lazer em domicílio principal.

Quanto aos guarapuavanos que possuem chácara de lazer em outros municípios, é possível identificar que, mesmo diante da grande extensão territorial do município de Guarapuava, existe uma tendência de pessoas que residem no município e se deslocam para outros municípios vizinhos, ao entorno de Guarapuava, para usufruir de momentos de lazer nos finais de semana.

Diante da realidade que se apresentou por meio da pesquisa empírica e, ainda, tendo em vista que a proposta inicial direcionava para o espaço rural do município, o estudo deparou-se com a decisão de aceitar ou refutar os questionários de proprietários que possuem chácaras no distrito sede de Guarapuava, que representa 25,84\% do total pesquisado.

Após tabulação dos dados e apreciação dos resultados foi decidido pela aceitação da amostragem correspondente aos domicílios de uso ocasionais instalados dentro do perímetro urbano do município de Guarapuava.

Justifica-se essa decisão considerando que os limites territoriais entre o urbano e o rural estão inseridos numa dinâmica sociocultural e econômica complexa, cercada de 
interpretações ambíguas, pois a sociedade capitalista não possibilita identificar esses espaços simplesmente pelas suas formas de produção ou pelas divisões sócio-espaciais do trabalho.

Nesse sentido, a realidade empírica no município de Guarapuava é similar aos problemas relacionados pela literatura consultada, uma vez que os conceitos de cidade e campo confundem-se e não se restringem a um território fixo, previamente demarcado (CAMARANO; ABROMOVAY, 1999).

Os espaços rurais e urbanos, que contemplam ruralidades em Guarapuava, também não apresentam limites e o que interessa nesta pesquisa, é o modo de vida, um estilo de vida, em que se propagam e se permutam costumes e hábitos, tanto rurais como urbanos, recebendo influencias e influenciando diferentes pessoas.

Assim, o modo de vida identificado neste estudo transcende os limites geográficos em busca da satisfação de interesses e ações existentes em ambos os espaços, o que corrobora para a decisão de analisar as novas ruralidades de Guarapuava, indiferentemente aos limites distritais.

Outra situação que justifica a aceitação da inclusão do referencial da área urbana diz respeito à distância dos centros populacionais. A qualidade ou os atributos da paisagem, a presença de recursos recreativos, a disponibilidade de terra, o clima das áreas emissoras e receptoras, entre outros fatores influenciam na localização dos domicílios de uso ocasional (ASSIS, 2003).

Conclui-se dessa forma que o número de questionários validados para a amostragem totalizaram 70 chácaras de lazer, que representam qualitativamente $10,16 \%$ do montante de 689 domicílios de uso ocasional recenseados pelo IBGE (2010), localizados nas ruralidades de Guarapuava. Ratifica-se que nesse extrato estão incluídos também os questionários dos citadinos inquiridos que possuem chácaras de lazer, na condição de domicílio de uso ocasional, situados no limites do perímetro urbano do município.

Esses fatores definem as características da paisagem de Guarapuava, considerando que, tradicionalmente, as áreas das chácaras de lazer, na condição de domicílios de uso ocasional, tendem a se distanciar do centro urbano na medida em que o perímetro urbano expande-se e se urbaniza em direção a áreas mais distantes, ao encontro da zona rural (LUNDGREN apud PEARCE, 2003). Dessa forma, existe 
possibilidade de, em um futuro próximo, as chácaras de lazer, hoje registradas na área urbana, serem transformadas em residências principais.

Outra situação a ser considerada é que existem chácaras de lazer localizadas na área urbana que provêm de heranças, visto que pela evolução do perímetro urbano do município, essas propriedades deixaram sua localização nos limites da área rural e foram oficializadas como urbanas, o que é respaldado por Assis (2003), considerando que o fenômeno em estudo esta ligado ao movimento geral da urbanização por meio de processos espaciais de expansão do tecido urbano que extrapolam os limites do centro urbano.

Destaca-se também que as sensações prazerosas de estar em meio à natureza motivam o constante retorno nos finais de semanas, feriados e férias para as paisagens com característica rurais.

O que corrobora na tendência de que os retornos cada vez mais frequentes a esses espaços, em um curto período de tempo, levam essas famílias a se tornarem proprietárias ou possuidoras, por herança ou pela compra, de propriedades nas proximidades ou no entorno da área urbana, para poderem usufruir do tempo do nãotrabalho com maior comodidade, sem perder muito tempo com o rotineiro deslocamento. O uso repetido de um mesmo espaço cria “[...] alguma forma de vínculo territorial e psicossociológico" (TULIK, 1995, p. 21).

Dessa forma, com a finalidade de caracterizar o fenômeno das chácaras de lazer na condição de domicílio de uso ocasional, passa-se a apresentar os aspectos, perfil e relações analisadas sobre objeto de estudo.

\subsection{Aspectos da posse, existência e preferência das chácaras de lazer}

A expressão "uso ocasional" relaciona-se com a concepção de tempo livre ou tempo do não trabalho, contextualizado eminentemente pela sociedade contemporânea, que suscita um tempo para o lazer e para a qualidade de vida, além de significar oportunidade de recompor as energias para o retorno às obrigações cotidianas.

$\mathrm{Na}$ contextualização de uma vida mais saudável, estreitam-se os elos entre o homem e o meio natural, dinamizando os desejos de pessoas citadinas residentes em Guarapuava a adquirir o hábito da vivência nas ruralidades locais. 
Quanto ao tempo de existência das chácaras de lazer do município, verificou-se que $25,71 \%$ das chácaras de lazer não ultrapassam 5 anos de existência; $17,14 \%$ possuem entre 10 a 20 anos; e aproximadamente $24 \%$ das chácaras de lazer possuem mais de 30 anos. A maior incidência está nas chácaras que possuem entre 5 a 10 anos, com aproximadamente $33 \%$ da amostra, o que evidencia um fenômeno relativamente recente em Guarapuava, considerando que observou-se uma considerável expansão a partir da década de 2000.

Um dos fatores que gera curiosidade é quanto às motivações que corroboram para a aquisição de uma chácara de lazer, bem como as razões que levam o citadino a adquirir esse tipo de propriedade. Observou-se que, entre os respondentes, a razão principal está em encontrar um local tranquilo, para passar o tempo livre, com a finalidade de descansar, repousar e aliviar a fadiga do trabalho.

Entretanto, a amostragem revelou outra situação, que a "qualidade paisagística e ambiental" é o fator que mais tem influenciado na definição da localização desse tipo de propriedade, apresentando-se como a opção principal para $40 \%$ dos inquiridos. Em seguida, a procura de um "espaço para descanso" é o principal argumento de 27,14\% dos respondentes. Observa-se com esse percentual que as chácaras de lazer em Guarapuava estão, essencialmente, associadas a uma paisagem natural ideal para o descanso.

Entretanto, a baixa dispersão de dados na relação com a variável "oportunidade de investimento", com 21,42\%, possibilita identificar que os proprietários também, indiretamente, consideram a propriedade um investimento rentável.

Apenas $11,42 \%$ dos inquiridos responderam que adquiriu a chácara de lazer levando-se em consideração a localização próxima à residência principal, o que significa que a distância entre a residência principal e o domicílio de uso ocasional não tem grande influencia na aquisição desse tipo de propriedade em Guarapuava.

Quanto às razões que promovem o desejo do citadino guarapuavano a adquirir uma chácara de lazer, verificou-se que 58,58\% dos inquiridos usa a propriedade como uma forma de "fuga da agitação da área urbana", para passar seus fins de semana e férias. O aspecto de "valorização da paisagem natural" representou $40 \%$ das respostas e a variável "retorno às origens", apenas $1,42 \%$. Isso leva a perceber que, mesmo sendo a propriedade herdada, poucos a consideram como uma volta ao passado. 
Esse resultado revela que os citadinos buscam as novas ruralidades, e não aquele rural que seus antepassados vivenciaram, ligado a um modo de vida com a ausência de desenvolvimento e limitações espaciais e econômicas (VEIGA, 2004).

Outro fator que merece análise é o modo de obtenção e ocupação das chácaras de lazer que, considerando que foi sinalidar que $82,86 \%$, das chácaras de lazer pesquisadas em Guarapuava-PR é própria (de um único dono) adquirida "por meio de compra, permuta ou outros". Apenas 17,14\% foram adquiridas por meio de herança, sendo que desse montante, $10 \%$ pertencentes a um único proprietário, $2,85 \%$ partilhadas entre parentes que residem no local e 4,30\% partilhadas por vários herdeiros.

Observa-se que não existe no estrato a ocorrência de propriedades emprestadas, alugadas, arrendadas ou partilhadas. O que corrobora com a observação de que essas propriedades têm por objetivo a utilização exclusiva para uso privado e não são utilizadas sob a perspectiva de um investimento, que pode ser rentabilizado por meio do seu arrendamento ou aluguel.

Nesse sentido, os citadinos proprietários disponibilizam maiores recursos financeiros para a manutenção, estruturação e melhoria das suas chácaras de lazer, realizando maiores investimentos. Diferente daqueles citadinos que utilizam esse tipo de propriedade, na condição de emprestada ou alugada.

Registrou-se também que os investimentos às chácaras de lazer apresentam relação direta com a frequência de utilização desse domicílio.

Destaca-se que a frequência de utilização da chácara de lazer é registrada, sistematicamente, com periodicidade semanal, tendo em vista a facilidade de mobilização e a proximidade com a área urbana de Guarapuava, caracterizada como pólo emissor.

\subsection{Perfil socioeconômico do usuário das chácaras de lazer}

O perfil dos usuários da chácara de lazer não pode ser generalizado, considerando que não existe um padrão comum para aplicação neste estudo. Dessa forma, a caracterização dos utilizadores desse tipo de propriedade no município de Guarapuava pode ser formada com base nos dados referentes ao estado civil, idade, ocupação, escolaridade e renda per capita. 
Inicialmente, parece que a única condição que comunga entre todos os usuários desse tipo de propriedade é o fato de terem condições e possibilidades financeiras para satisfazer o desejo de ser proprietário de uma chácara de lazer.

Entretanto, os estudos indicam a possibilidade de identificar algumas similaridades entre os proprietários, com referência as suas características, bem como seus comportamentos, de acordo com incidências dos casos de estudo.

Nesse caminho, observou-se por meio das respostas que os usuários das chácaras de lazer residem e trabalham na área urbana de Guarapuava, possuem tempo disponível para usufruir da chácara de lazer e têm meios próprios para se deslocar, a qualquer tempo, até a propriedade.

Destaca-se que os usuários proprietários desse tipo de imóvel possuem uma renda compatível com as exigências de manutenção, deslocamento e investimentos nos referidos imóveis.

Verificou-se os proprietários apresentam uma renda per capita de 5 a 10 salários mínimos; 22,85\% recebem de 10 a 20 salários mínimos; $14,28 \%$ percebem mais de 20 salários mínimos e os demais proprietários tem uma renda média abaixo de 5 salários mínimos.

A relação assimétrica das rendas médias dos proprietários tem relação com a ocupação funcional do usuário proprietário da chácara de lazer.

Os resultados dos rendimentos dos proprietários corroboram na identificação de uma condição favorável, por parte da maioria da amostragem, para a manutenção desse tipo de propriedade, o que propicia a possibilidade de um dispêndio econômico vinculado a estadia, locomoção, impostos e taxas públicas, além dos possíveis investimentos para a manutenção da propriedade..

Observa-se que as maiores frequências indicam ocupações no funcionalismo público estadual e no empreendimento autônomo (empresários), respectivamente. As ocupações registradas refletem categorias profissionais com remunerações acima da média, o que induz a concluir que os inquiridos pertencem à classe média e com boa qualificação profissional, fato que pode justificar a aquisição e manutenção das chácaras de lazer, bem como a disponibilidade do tempo para o lazer.

A profissão e os rendimentos dos proprietários das chácaras de lazer de Guarapuava ratificam o padrão descrito pela literatura consultada e permitem identificar 
uma condição propícia a dispêndios econômicos em relação a gastos e investimentos nas chácaras de lazer impactando na localidade onde estão instaladas essas propriedades, com possibilidade de apresentar sinergias, tanto positivas quanto negativas, na dinâmica da comunidade local.

Observou-se que 91,43\% dos inquiridos possuem mais de 36 anos de idade, apresentando-se casados ou em união estável. Apenas 8,57\% possuem menos de 35 anos, o que leva a acreditar que essa faixa etária corresponde, essencialmente, a um grupo da população que se encontra no início do ciclo da sua vida familiar e profissional, restringindo as condições econômicas para aquisição e manutenção de uma chácara de lazer.

Observou-se, ainda, por meio da caracterização da idade e do estado civil, que os proprietários das chácaras de lazer são pessoas que estão, na sua maioria, ativas no mercado de trabalho, e que buscam meios alternativos para descanso e lazer nos finais de semana, valorizando assim, a qualidade de vida de seus familiares e fugindo, de certa forma, da rotina estressante do dia-a-dia urbano.

\subsubsection{As relações estabelecidas a partir das chácaras de lazer.}

O fenômeno das chácaras de lazer na condição de domicílio de uso ocasional, apresenta relação direta com as demandas de citadinos que buscam um espaço de lazer, recreação, descanso e tranquilidade, além da expectativa de participar das novas ruralidades, com vista à valorização da paisagem natural.

Uma grande parte dos citadinos que procura esse tipo de paisagem é de pessoas que tiveram contato com o espaço rural na infância ou que tiveram pais ou avós que tinham ligação com o meio rural, conforme destacado pelos entrevistados.

Atualmente, esses citadinos, proprietários de chácaras de lazer, não têm identificação com a agropecuária, desenvolvendo apenas algum tipo de atividade ligada à terra, porém não intensiva. Para tanto, utilizam prioritariamente mão de obra de membros da família de pequenos agricultores para a manutenção da propriedade, pois, segundo Graziano da Silva (1999), as chácaras de lazer demandam serviços tais como os realizados por caseiros, jardineiros, empregados domésticos, dentre outros.

Quanto à frequência de utilização das chácaras de lazer, os entrevistados 
indicaram o uso preferencial nos finais de semana e nos feriados, declarando que os filhos com maior idade não frequentam regularmente a propriedade. $\mathrm{O}$ maior índice de permanência é sempre do casal, com faixa etária acima dos 36 anos. Isso ocorre, possivelmente, porque o casal detém estabilidade econômica.

Essa é uma realidade que, paulatinamente, se insere nas localidades dos distritos administrativos de Guarapuava, que passam a experimentar impactos de diferentes ordens, principalmente para a comunidade local, onde a maioria dos moradores tem carências diversas a serem consideradas em relação à manifestação e expansão do fenômeno das chácaras de lazer.

Observou-se que cada chácara de lazer é frequentada, em média, por 5 pessoas, com a finalidade exclusiva de descanso e lazer, conforme as informações dos inquiridos. Os indivíduos que visitam as chácaras de lazer, em sua maioria, são parentes e amigos que residem na área urbana de Guarapuava, com exceção de alguns parentes que esporadicamente visitam a propriedade por morarem em outras cidades ou estados.

No caso deste estudo, considera-se como pólo emissor o centro urbano de Guarapuava, pois é o principal ponto de origem dos deslocamentos em direção a esse tipo de propriedade.

Destaca-se que no estrato pesquisado, os distritos Sede e do Guará são os principais pólos receptores de visitantes, verificando-se que a distância entre o pólo emissor e receptor não interferiu no deslocamento dos usuários para esse tipo de lazer, já que os dois distritos apresentam os extremos em distância, considerando que o distrito Sede apresenta em média $10 \mathrm{Km}$ de distância, enquanto o distrito de Palmeirinha apresenta em média $25 \mathrm{Km}$ de distância da área urbana de Guarapuava.

Quanto à temporariedade, de acordo com as informações prestadas pelo questionário aplicado, a maioria dos usuários apresenta fluxos de visitação usualmente nos finais de semanas, em função do tempo livre, que varia basicamente no tempo de não-trabalho. Observou-se que a periodicidade fica mais acentuada, até mesmo durante a semana, após a aposentadoria do provedor da família.

Destaca-se que, durante a realização das entrevistas junto à comunidade local, observou-se que os impactos ocasionados pelo fenômeno das chácaras de lazer, na condição de domicílios de uso ocasional, não são aparentemente significativos e muitas vezes não são percebidos no contexto geral da localidade. 
Todavia, quando algum membro das famílias locais passa a trabalhar como caseiro ou presta algum tipo serviços para as chácaras de lazer, a relação fica mais expressiva e visível, considerando que esse tipo de relacionamento representa uma renda extra complementar para a família do pequeno agricultor que reside próximo à chácara de lazer. A família do proprietário da chácara de lazer tem mais interação e integração com a comunidade local quando se estabelecem contratos de trabalho com moradores originários dela.

A interação dos citadinos, ocupantes das chácaras de lazer, com a comunidade local aumenta na medida em que a família do empregado também passa a frequentar a propriedade, estabelecendo relações e, até mesmo residindo na própria chácara de lazer, na condição de caseiros dessa propriedade. Dentre as propriedades visitadas, quatro possuem caseiros que tomam conta do espaço, contribuindo para a manutenção da chácara de lazer.

Esse tipo de relação é bem visível no relato de uma esposa de empregado, ao informar que os patrões gostam muito do pão caseiro assado em forno à lenha e até fazem encomendas para levar para a cidade. Outra declaração significativa indica que quando há frutas colhidas na propriedade, a esposa do caseiro faz doces, compotas e geleias caseiras para os patrões levarem, além destes se interessarem pelas suas receitas e por como são feitos os bolos e pratos típicos que são consumidos localmente.

A realidade observada promove a integração desses atores sociais, que são influenciados por uma vivência diferente daquela vivida diariamente. De um lado, a comunidade local tem acesso às modernidades funcionais trazidas pelos citadinos e, de outro, os citadinos acostumados com produtos industrializados passam a consumir produtos feitos na própria propriedade, com a ajuda das pessoas da comunidade.

Em outra chácara de lazer visitada, a esposa do proprietário informou que a família do caseiro é fundamental e indispensável para o bom funcionamento da propriedade e para o desfrute do lazer e do descanso quando da estadia na chácara. Ela disse que: "Em outros tempos, quando não possuía caseiro (que residia com sua família na chácara), eles vinham para a chácara apenas para trabalhar e não conseguiam descansar". Relatou ainda que "[...] são feitas as compras mensais de produtos alimentícios para a família do caseiro nos mercados da cidade e, em troca, quando eles chegam na chácara, nas sextas-feiras a noite, são recebidos com um feijão quentinho e 
uma couve tirada do quintal - ingredientes para o preparo de um delicioso virado de feijão", prato bem comum localmente.

Registrou-se, ainda, que a maioria dos proprietários de chácaras de lazer compram os produtos a serem utilizados ou consumidos na chácara de lazer em supermercados, no centro urbano. Apenas alguns produtos, principalmente alimentícios produzidos artesanalmente, são adquiridos na localidade onde está instalada a propriedade.

Destaca-se que a comunidade local possui um potencial econômico de gastronomia que envolve pães, bolachas, embutidos, conservas e geleias caseiras.

O consumo local ocorre no setor de serviços, principalmente a contratação de serviços de caseiro permanente. Observa-se que a ausência do consumo dos produtos locais está associada à falta de divulgação, informação ou integração entre os moradores e os proprietários das chácaras.

Quanto às alternativas de complementação de renda para os pequenos agricultores nos espaços onde se localizam as chácaras de lazer, são detectadas contratações de mão-de-obra para execução de serviços. Foi identificado que 82,85\% das chácaras de lazer pesquisadas possuem empregados permanentes contratados para fazer frente às demandas de manutenção da infraestrutura da propriedade. Destaca-se que $17,15 \%$ da propriedades contratam temporariamente mão de obra para serviços específicos.

Registra-se que todos os respondentes confirmaram a necessidade de contratação de mão-de-obra permanente ou temporária e se observou também que, na sua maioria, contratam apenas um empregado na condição de "caseiro" e, esporadicamente, contratam outros para trabalho temporário.

Quanto à origem do trabalhador da chácara de lazer, observou-se que 51,42\% das pessoas que trabalham na condição de funcionário permanente nessas propriedades vem de outra localidades. Em contrapartida, 48,58\% contratam trabalhadores da própria localidade.

A investigação a respeito da origem do trabalhador da chácara de lazer é importante diante dos efeitos que essa prática ocasiona nos espaços onde se instala esse tipo de propriedade, considerando as possibilidades de renda extra para as famílias dos pequenos agricultores, constituindo-se numa das características da pluriatividade. 
Assim, os serviços contratados temporariamente, que representam 17,14\% dos 70 entrevistados, são todos da comunidade local e executam as seguintes tarefas: reparos em geral e auxilio em atividades rurais desenvolvidas na propriedade para o sustento e lazer da família do proprietário - horta, pomar, tanque de peixe, ornamentação, reserva de lenha e outros.

Quanto às relações das chácaras de lazer com a comunidade local, observou-se que elas são mantidas na base de troca em épocas de safra de algum produto, em que os produtos excedentes são permutados e muitas vezes distribuídos entre os moradores vizinhos da chácara.

A troca de favores ou a contratação por empreitada ou diária são outros fatores de integração, considerando que os moradores locais ajudam na lida com os animais, nos afazeres com a horta e/ou pomar e junto aos tanques de peixes.

O que parece peculiar entre os entrevistados da comunidade é a falta de um espaço comunitário próprio ou para eventos festivos locais, o que contribuiria para a integração dos ocupantes das chácaras de lazer com a comunidade local, considerando que muitas das pessoas relataram que nas festas da Igreja local ocorre a possibilidade de conhecer a vizinhança.

A esse respeito, observou-se que a maioria dos proprietários citadinos das chácaras objetiva apenas descansar no âmbito da própria residência e não se sente propensos a participar das atividades festivas da comunidade local - com exceção das festas da Igreja local, onde a família citadina participa das brincadeiras e desfruta do churrasco nos almoços comunitários.

Quanto à atuação do poder público local na organização espacial das chácaras de lazer, constatou-se sua inércia, levando a considerar que o fenômeno é pouco conhecido pelo governo do município e não apresenta perspectivas de ações futuras.

Quanto à questão ambiental, os entrevistados revelaram a preocupação em manter a natureza preservada e que não há o interesse na exploração econômica.

As observações empíricas e experiências vividas levam a perceber que nas paisagens onde se instalam as chácaras de lazer existem impactos - alguns visíveis, outros ocultos - em decorrência da integração social, econômica e cultural, bem como devido às trocas de experiências entre os moradores locais e as famílias dos proprietários das chácaras de lazer, considerando que nas visitas foram observados 
vínculos dos citadinos com o espaço rural.

Independente das motivações ou fatores que compõem os impactos do fenômeno das chácaras de lazer e, não buscando defender unilateralmente, se faz necessário elencar alguns fatores positivos e negativos, de maior relevância, observados em Guarapuava.

Os aspectos positivos de maior relevância foram os seguintes:

- complemento de renda aos agricultores: foram registrados intercâmbios de produtos, aliado à pluriatividade por meio da prestação de serviços que se fazem necessário às demandas da chácara de lazer;

- valorização dos recursos naturais ambientais: diz respeito ao valor simbólico das ruralidades para a sociedade contemporânea guarapuavana, por meio da procura e do consumo pelos citadinos de áreas rurais do município, buscando a valorização e a preservação dos recursos naturais existente nas chácaras de lazer;

- revitalização de áreas deprimidas: observou-se que as chácaras de lazer passam a ser uma alternativa concreta na ocupação de áreas rurais e urbanas no município, com terrenos impróprios, que se apresentam com baixa capacidade produtiva para a agricultura e pecuária;

- investimentos imobiliários: esse fator está ligado às questões econômicas por meio da valorização de terrenos, de áreas e de estruturas físicas e infra-estrutura, que está aliado aos esforços dos empresários do município;

- geração de empregos diretos e indiretos: foram registrados, mesmo que sintetizado, a contratação de mão-de-obra na condição de caseiro ou diaristas, bem com por empreitada;

- valorização de hábitos e costumes locais: diz respeito à construção da identidade, constituído por meio dos valores simbólicos que são fortalecidos com a integração dos citadinos guarapuavanos, que são frequentadores das chácaras de lazer e da comunidade local;

- renovação e/ou recuperação das habitações: notou-se a capacidade de valorização das construções e tipologias locais, considerando que os respondentes conservam construções pré-existentes na chácara de lazer.

Quanto aos aspectos negativos, foram observados com maior incidência, o que segue: 
- diminuição da área agrícola e florestal: atentou-se que existe uma certa diminuição da área que poderia ser destinada à agricultura e foi transformada pelo homem para a construção da sede da chácaras de lazer;

- degradação ambiental: assistiu-se que, quando da construção das chácaras de lazer nas ruralidades de Guarapuava, em benefício da valorização dos aspectos potenciais ao local, foi transformado os recursos naturais dessa área;

- especulação imobiliária: notou-se que existe uma certa supervalorização de terrenos nas ruralidades de Guarapuava, pela perspectivas de preservar o capital financeiro, principalmente nas áreas de grande potencial de recursos ambientais; e

- alteração de hábitos e costumes locais: observou-se que os proprietários das chácaras de lazer acrescentam adjetivos ao lugar, com respeito à arquitetura, ao patrimônio e ao lazer que não se harmoniza com a realidade local, além de interferir nas relações pré-existentes, introduzindo usos e costumes urbanos.

Essas são algumas das observações sobre os impactos relacionados às mudanças do modo de vida dos moradores da comunidade local, onde se instalam as chácaras de lazer, que estão associadas às diversas relações mantidas com as famílias e visitantes das chácaras de lazer.

O que se pode depor é que o mundo contemporâneo vive um paradoxo, cuja tendência é pela tecnologia avançada e a globalização, que pelo sua própria natureza, apresenta-se efeitos positivos e negativos, que fazem parte do desenvolvimento e/ou evolução humana.

No entanto, as pessoas também estão procurando por alguns momentos de isolamento, e o individualismo ainda impera nas relações, mesmo que temporariamente, nas chácaras de lazer estudadas.

\section{CONSIDERAÇÕES FINAIS}

As vivências nas ruralidades do município de Guarapuava-PR, a partir a possibilidade de mobilidade nos finais de semana e tempo do não-trabalho, é decorrente de um sistema contemporâneo capitalista. Uma sociedade estruturada em classes que buscar um lazer diferenciado ligado ao seu nível econômico-financeiro.

Esse cenário também é registrado na sociedade guarapuavana, onde estão 
emergindo novos estratos sociais que passam a incorporar um lazer em meio às ruralidades locais.

Destaca-se que essa ruralidade não denota limites espaciais e sociais, penetra heterogeneamente nos espaços rurais e urbanos de forma a consumir tais espaços em um processo dinâmico face à incorporação cultural de novos valores, hábitos e costumes.

Dessa forma, observou-se que esse espaço com características rurais, que incorpora a cultura local, aderiu ao desenvolvimento e à globalização cibernética sem, entretanto, deixar de ser rural.

E é justamente esse espaço, com ruralidade, que os citadinos têm buscado, conformam relações e teias interdependentes de processos econômicos, sociais e culturais entre rural e urbano, fazendo expandir o fenômeno das chácaras de lazer na condição de domicílio de uso ocasional.

Nesse espaço que ressalta o vínculo com a terra, congrega também o descanso e lazer, além da preservação cultural e ambiental.

Com destaque para as ruralidades guarapuavana que apresentam paisagens cada vez mais valorizadas, constituindo um cenário que agrega uma diversidade de formas de uso e ocupação do solo, que modelam um espaço híbrido onde se implantam diferentes formas, funções, estrutura e processo, para os diferentes estilos de moradias e construções, promovendo relações promissoras, não antagônicas entre o rural e urbano.

Destaca-se que o processo de desenvolvimento do município não conseguiu desvincular os guarapuavanos de suas características culturais, configuradas a partir da sua trajetória ao longo dos anos, que conserva suas raízes vinculadas ao campo e à terra. Esse perfil moldou a vida da cidade e favoreceu as transformações socioculturais e espaciais, moldando as ruralidades locais.

Os reflexos e repercussões das chácaras de lazer, como domicílio de uso ocasional, ainda estão encolhidos e não diagnosticados, porém, a expansão do fenômeno a partir de 2000 permite apontar para a necessidade de ações prognósticas a respeito dos impactos desse fenômeno no espaço local.

Acredita-se que este estudo não encerra as análises e as discussões que ainda restam serem levantadas acerca dessa temática, mas busca-se contribuir para reflexões sobre a nova dinâmica existente no espaço do município de Guarapuava-PR, cooperando para futuros estudos e para o esforço conjunto a outros pesquisadores. 


\section{REFERÊNCIAS}

ALENTEJANO, P. R. R. O que há de novo no rural brasileiro? In: Geografia, política e cidadania. Revista Terra Livre, v.2, n.15, p. 87-112, jul/ dez, 2000.

Pluriatividade: uma noção válida para a análise da realidade brasileira? In: TEDESCO, J. (Coord.) . Agricultura familiar: realidades e perspectivas. 3 ed. Passo Fundo (RS): UPF, 2001. p.149-175.

As relações cidade-campo no Brasil do século XXI. Revista Terra Livre, São Paulo, v.2, n.21, p.25-39, jul/dez., 2003.

ALMEIDA, J. A. A função estética e recreativa da agricultura. In: OLIVEIRA, C. G. de S.; MOURA, J. C. de. O turismo rural como vetor do desenvolvimento sustentável. IN: $4^{\circ}$ CONGRESSO BRASILEIRO DE TURISMO RURAL. Anais... Piracicaba, FEALC, 2003, p. 449-457.

ANJOS, F. S. Agricultura familiar, pluriatividade e desenvolvimento rural no sul do Brasil. Pelotas (RS): EGUFPEL, 2003.

ANSARAH, Marília G. dos R. Estudo comparativo e perfil do agente cultural no Brasil e no México. Memorial da América Latina e Museo Nacional de Culturas Populares. Tese (Doutorado Cultura e Turismo) - Escola de Comunicação e Artes, Universidade de São Paulo, 1993.

ASSIS, Lenilton F. Análise geomorfológica: um aporte ao estudo da difusão do turismo de segunda residência nas paisagens do litoral sul da Ilha de Itamaracá-PE. Revista de Geografia [da] Universidade Federal de Pernambuco, Recife, v. 16, n. 2, p. 11-39, jul./dez.,2000.

A difusão do turismo de segunda residência nas paisagens insulares: um estudo sobre o litoral sul da Ilha de Itamaracá - PE. 177 f. Dissertação (Mestrado em Geografia) - Centro de Filosofia e Ciências Humanas, Universidade Federal de Pernambuco, Recife, 2001.

- Turismo de segunda residência: a expressão espacial do fenômeno e as possibilidades de análise geográfica. Revista Território. Rio de Janeiro: ano VII, n. 11, 12 e 13, p 107-122, set./out., 2003.

Residências secundárias: expansão e novos usos no litoral cearense. In: SILVA, José B. da. et al (Orgs.). Litoral e sertão: natureza e sociedade no nordeste brasileiro. Fortaleza: Expressão Gráfica, 2006. p. 289-305

BARBOSA, Cristina. Segunda Residência e Cidade Difusa. In: COLÓQUIO IBÉRICO DE GEOGRAFIA. Atas... Évora (Portugal), APG; Universidade de Évora, 2005.

BENI, Mário Carlos. Análise Estrutural do Turismo. 10ª ed. São Paulo: Editora Senac, 2004. 
BERNARDES, Jamile R. Chácaras para lazer: uma expressão do "novo rural brasileiro". 2005. Trabalho de Conclusão de Curso (Bacharelado em Geografia) Universidade Estadual de Londrina, Londrina, 2005.

BERNARDES, Jamile R.; ANTONELLO, Ideni T. A interface entre a implantação de chácaras para lazer e a constituição do "novo rural brasileiro". Campo-Território: revista de geografia agrária, Uberlândia, v.4, n. 7, p. 112-139, fev. 2009.

BRANDÃO, Carlos R. Do sertão à cidade: os territórios da vida e do imaginário do camponês tradicional. In: MESQUITA, Zilá; BRANDÃO, Carlos (Orgs). Territórios do Cotidiano: uma introdução a novos olhares e experiências. Porto Alegre: UFRGS; Santa Cruz do Sul (RS): Universidade de Santa Cruz do Sul - UNISC, 1995.

CALDEIRA, Maria José Boavida. Residência Secundária na área metropolitana de Lisboa: outros espaços, outras vivências. Dissertação (Mestrado em Geografia Humana e Planejamento Local e Regional), Faculdade de Letras, Universidade de Lisboa, Lisboa (Portugal), 1995.

CANDIOTTO, Luciano Z. P.; CORRÊA, W. Kruger. Desenvolvimento rural sustentável: algumas considerações sobre o discurso oficial do governo federal. Geografia, Rio Claro, v. 29, n. 2, p. 265-280, 2004.

CANDIOTTO, Luciano Z. P.; CORRÊA, W. Kruger. Ruralidades, urbanidades e a tecnicização do rural no contexto do debate cidade-campo. Campo-Território: revista de geografia agrária. v.3, n. 5, p. 214-242, fev., 2008. Disponível em: < http://www.campoterritorio.ig.ufu.br>. Acesso em: 15 fev. 2012.

CARNEIRO, M. J. Ruralidade: novas identidades em construção. Estudos Sociedade e Agricultura, Rio de Janeiro, n.11, p. 53-75, out. 1998.

CARNEIRO, M. J. Pluriatividade da agricultura no Brasil: uma reflexão crítica. In: I COLÓQUIO DE AGRICULTURA FAMILIAR E DESENVOLVIMENTO RURAL. Anais... Porto Alegre: GEPAD/PGDR/ UFRGS, 2005

CARNEIRO, M. J.. Pluriatividade da agricultura no Brasil: uma reflexão crítica. In: SCHNEIDER, Sergio (Org.). A diversidade da agricultura Familiar. Porto Alegre: UFRGS, 2006. p.165-185.

CORRÊA, Walquíra K. Desafios para a geografia rural na contemporaneidade: questões para o debate. In: $4^{\circ}$ ENCONTRO NACIONAL DE GRUPOS DE PESQUISA, São Paulo, ENGRUP, p. 278-295, 2008.

CRAVIDÃO, Fernanda Delgado. Residência secundária e espaço rural - duas aldeias na serra da Lousã : Casal Novo e Talasnal. Coimbra: Faculdade de Letras, 1989.

DEL GROSSI, M. E. Evolução das ocupações não-agrícolas no meio rural brasileiro, 1981- 95. Tese (Doutorado em Economia) - Instituto de Economia, Universidade Estadual de Campinas, Campinas, 1999. 
DEL GROSSI, M. E.; SILVA, J. G. A pluriatividade na agropecuária brasileira em 1995. In AGUIAR, D.; PINHO, J. B. (Eds.) O agronegócio brasileiro: desafios e perspectivas, Brasília: Sober, 1998. p. 635-646.

FAJARDO, Sérgio. Paisagem rural e território econômico: possibilidades de leitura do espaço geográfico. In: XIV SEMANA DE GEOGRAFIA: GEOGRAFIA E CINEMA: PODER, TERRITORIALIDADE E MOVIMENTOS SOCIAIS - Departamento de Geografia da Universidade Estadual do Centro-Oeste. Anais... Guarapuava: Unicentro, 2005.

da Unicentro, 2008.

Territorialidades corporativas no rural paranaense. Guarapuava: Editora FERREIRA, Angela D. Processos e sentidos sociais do rural na contemporaneidade: indagações sobre algumas especificidades brasileiras. Estudos Sociedade e Agricultura, Rio de Janeiro, n. 18, p. 28-46, 2002.

FERREIRA, Sandra C.. Rede urbana, cidades de porte médio e cidades médias: estudos sobre Guarapuava no estado do Paraná. Presidente Prudente : [s.n], 2010.

A formação socioespacial como orientação teórico-metodológica no estudo da rede urbana regional. Caminhos de Geografia, Uberlândia, v. 12, n. 37, p. 1-7, mar, 2011. Disponível em <http://www.ig.ufu.br/revista/caminhos.html $>$. Acesso em: 04 mar. 2012.

GARCIA, Rita M. de P.. Análise da dinâmica sócio-espacial de uma área ribeirinha: um estudo das residências secundárias do rio Sucuriu em Três Lagoas-MS. Dissertação (Mestrado em Geografia) - Universidade Federal de Mato Grosso do Sul, Aquidauana (MS), 2007.

GIULIANI, G. M. Neo-ruralismo: o novo estilo dos velhos modelos.Revista Brasileira de Ciências Sociais, São Paulo, ANPOCS, v. 14, ano 15, p. 59-67, 1990.

GODOY, A. S. Introdução à pesquisa qualitativa e suas possibilidades. Revista de Administração de Empresas, Rio de Janeiro, v. 35, n. 2, p. 57-63, mar./abr., 1995.

GOMES, Pedro Henrique Oliveira. Urbanização Perimetropolitana e a Organização Espacial das Residências Secundárias no Estado do Rio de Janeiro. In: ENCONTRO NACIONAL DE ESTUDOS POPULACIONAIS, XVI , 2008, Caxambu - MG. Anais eletrônicos... Caxambu: instituição ou editora, 2008. Disponível em: < http://www.abep.nepo.unicamp.br/ encontro2008/docsPDF/ABEP2008_990.pdf.>.

Acesso em: 16 nov. 2011.

GRAZIANO DA SILVA, José. O novo rural brasileiro. Campinas: Unicamp, 1999.

Velhos e novos mitos do rural brasileiro. Estudos Avançados, São Paulo, v. 15, n. 43, p. 37-50, $2001 \mathrm{~b}$. 
GRAZIANO DA SILVA, J.; DEL GROSSI, M. E. O uso das PNADS para as áreas rurais. Rio de Janeiro: IPEA, 2002.

GRAZIANO DA SILVA, J.; DEL GROSSI, M.E. A distribuição da população rural brasileira economicamente ativa 1981/1995. Espaço e geografia. Brasília: UNB/GEA, 1999. p.95-110. Disponível em: <http://www.eco.unicamp.br/projetos/rurban25.html>. Acesso em: 18 fev. 2012.

GRAZIANO DA SILVA, J.; DEL GROSSI, M.E. A evolução das rendas e atividades rurais não-agrícolas no Brasil. In: V SIMPOSIO LATINO-AMERICANO SOBRE INVESTIGAÇÃO E EXTENSÃO EM SISTEMAS AGROPECUÁRIOS - IESA, 2002, Florianópolis. Programação e Caderno de Resumos. Florianópolis : EPAGRI, 2002. v. I. p. 83. Disponível em: <http://www.eco.unicamp.br/projetos/evolucaorendas.html>. Acesso em: 18 mar. 2012.

GRAZIANO DA SILVA, José et al. Turismo em áreas rurais: suas possibilidades e limitações no Brasil. In: ALMEIDA, J.A. et al. Turismo Rural e Desenvolvimento Sustentável. Santa Maria (RS): Centro Gráfico,1998.

GUARAPUAVA. Lei $\mathrm{n}^{\circ}$ 1.101/2001. Plano Diretor da Municipal de Guarapuava. Guarapuava: Câmara dos Vereadores de Guarapuava, 2001.

Refúgio para quem procura descanso e lazer. Disponível em: $<$ http://www. grpceeparlindoribeiro.seed.pr.gov.br/redeescola/escolas/14/950/118/arquivos/File/ESTA GUARAPUAVA.pdf >. Acesso em 19 abr. 2012.

HAESBAERT, Rogério. O mito da des-territorialidade: do fim dos territórios à multiterritorialidade. 2 ed. Rio de Janeiro: Bertrand Brasil, 2006

HAGUETTE, T.M. Metodologias qualitativas na sociologia. 2.ed. Petrópolis: Vozes, 1990.

HOUAISS, Antonio; VILLA, Mauro de Salles. Dicionário Houaiss da Língua Portuguesa. Rio de Janeiro, Objetiva, 2001.

INSTITUTO BRASILEIRO DE GEOGRAFIA E ESTATÍSTICA. Censo Demográfico. Brasil. Rio de Janeiro, IBGE, 1970.

Sinopse Preliminar do Censo Demográfico. Rio de Janeiro: IBGE, 1981.

Sinopse Preliminar do Censo Demográfico. Rio de Janeiro: IBGE, 1991.

Conceituação das Características Divulgadas na Contagem da População

de 1996. Rio de Janeiro, IBGE, 1996. Disponível em: <http:// www.ibge.gov.br/home/ estatistica/populacao/contagem/conceitos.shtm>. Acesso em 15 fev. 2012.

Sinopse Preliminar do Censo Demográfico. Rio de Janeiro: IBGE, 2000

Geo UERJ - Ano 15, nº. 24, v. 2, $2^{\circ}$ semestre de 2013

ISSN: 1415-7543E-ISSN: 1981-9021

http://www.e-publicacoes.uerj.br/index.php/geouerj 
. Sinopse Preliminar do Censo Demográfico. Rio de Janeiro: IBGE, 2010.

Página Principal do IBGE. Rio de Janeiro: IBGE, 2012. Disponível em: http://www.ibge.gov.br.

INSTITUTO PARANAENSE DE DESENVOLVIMENTO ECONÔMICO E SOCIAL. Leituras Regionais: Mesoregião Geográfica Centro-Sul Paranaense. Curitiba: IPARDES, BRDE, 2004.

Disponível

Anuário Estatístico do Estado do Paraná. Curitiba: IPARDES, 2010. <http://www.ipardes.pr.gov.br/anuario_2010/5indicadores/tab5_1_2.xls>. Acesso em: mar. 2012.

Taxa Anual de Crescimento Populacional, segundo a situação de Domicílio - Paraná - 1940/2010. Curitiba: IPARDES, 2011. Disponível em: <http://www.ipardes.gov.br/ pdf/indices/crescimento_populacional_atualizado_maio_2011 .pdf $>$. Acesso em: abr. 2012.

Página principal do IPARDES. Curitiba: IPARDES, 2012. Disponível em: http://www.ipardes.gov.br/

LEFEBVRE, Henri. Espaço e Política.. [s.1.:s.n.], 2003.

LUNDGREN, J. O. J. On access to recreational lands in dynamic metropolitan hinterlands. Tourist Review, Montreal (Canadá), Universidade McGill, v. 29, n. 4, p.124-131,1974.

MICHAELIS. Moderno Dicionário da Língua Portuguesa. Disponível em: <http://michaelis.uol.com.br/moderno/portugues/> Acesso em: 10 fev. 2012.

MOREIRA SCHNEIDER, Michelle M. O Parque Nacional De Ilha Grande, produção e consumo do território turístico. Dissertação (Mestrado em Geografia) Faculdade de Ciências Humanas, Universidade Federal do Grande Dourados, Dourados (MS), 2009.

PEARCE, Douglas. Tourism today - a geographical analysis. New York: Longman. 1991.

Geografia do Turismo. São Paulo: Aleph, 2003.

PELLEGRINI FILHO, Américo. Dicionário enciclopédico de ecologia e turismo. $1^{\mathrm{a}}$. ed. São Paulo: Manole, 2000, p. 90.

PREFEITURA DE GUARAPUAVA. Fotos. Disponível em: <http://www.guarapuava.pr.gov.br/turista/fotos/>. Acesso em: 19 abr. 2012

História. Disponível em: <http://www.guarapuava.pr.gov. br/ 
conheca/historia.php>. Acesso em: 15 mar. 2012.

RIEDL, M.; ALMEIDA, J. A.; VIANA, A. L. B. Turismo Rural: Tendências e sustentabilidade. Santa Cruz do Sul: Ed. Da Unisc, 2002.

ROCA, Maria de Nazaré Oliveira. Segundas residências em meio rural: o caso da região oeste. In: COLÓQUIO IBÉRICO DE GEOGRAFIA, XI, 1 a 4 de outubro de 2008, Alcalá de Henares, Portugal. Actas... Alcalá de Henares, 2008. Disponível em: <http://tercud.ulusofona.pt/Publicacoes/2008/com-P2-07.pdf>. Acesso em 2 dez. 2011.

RODRIGUES, Adyr Balastreri. Turismo e espaço. São Paulo: Hucitec. 1997.

Turismo eco-rural: interfaces entre o ecoturismo e o turismo rural. In: ALMEIDA, Joaquim Anécio; FROEHLICH, José Marcos; RIEDL, Mário (Orgs.). Turismo rural e desenvolvimento sustentável. Campinas: Papirus, 2000. p. 111-126.

Desafios para os estudiosos do turismo. In: RODRIGUES, A. B. (org.). Turismo e Geografia: reflexões teóricas e enfoques regionais. $3^{\text {a }}$ ed. São Paulo: Hucitec, 2001b, p. 17-32.

Hucitec, 2001a.

Turismo e Espaço: rumo ao conhecimento transdiciplinar. $3^{\mathrm{a}}$. ed. São Paulo:

RUA, João. A ressignificaçao do rural e as relações cidade-campo: uma contribuição geográfica. Revista da ANPEGE, Rio de Janeiro, n. 2, p. 45-66, 2005.

Urbanidades e novas ruralidades no estado do Rio de Janeiro: algumas considerações teóricas. In: MARAFON, Glaucio José e RIBEIRO, Marta Foeppel (Orgs.). Estudos de Geografia Fluminense. Rio de Janeiro: UERJ/CTC-IGEO-Depto. de Geografia, 2002, p. 27-42.

SACCO DOS ANJOS, Flávio; CALDAS, Nádia V. Pluriatividade e sucessão hereditária na agricultura familiar. In: SCHNEIDER, Sergio (Org.). A Diversidade da Agricultura Familiar. Porto Alegre: Ed. UFRGS, 2006. p. 186-212.

SAMARA, Beatriz Santos; BARROS, José Carlos de. Pesquisa de Marketing: conceitos e metodologia. $2^{\text {a }}$. ed. ampliada e revisada. São Paulo: Atlas, 1997.

SAMPAIO, Helena Maria Sant'Ana. O ensino superior no Brasil: o setor privado. São Paulo: Hucitec, FAPESP, 2000.

SANTOS, Milton. Espaço e método. São Paulo: Studio Nobel, 1985

.Metamorfoses do Espaço Habitado. São Paulo: Hucitec, 1988.

A Urbanização Brasileira. São Paulo: Hucitec, 1994.

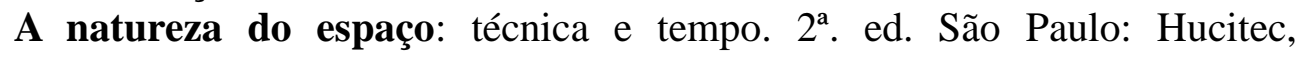
[1996]1997. 
Metamorfoses do Espaço Habitado: fundamentos teóricos e metodológicos da geografia. São Paulo: Hucitec, 1997.

Por Uma Outra Globalização. Rio de Janeiro: Record, 1999.

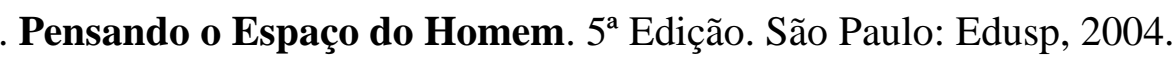

SANTOS, Milton; SILVEIRA, M. L. Brasil: Sociedade e Território no Início do Século XXI. Rio de Janeiro: Record, 2001.

SANTOS, Milton et al. Território e sociedade: entrevista com Milton Santos. São Paulo: Editora Fundação Perseu Abramo, 2000.

SANTOS, Milton; RIBEIRO, Wagner Costa (org). O país distorcido: o Brasil, a globalização e a cidadania. São Paulo: Publifolha, 2002.

SCHMIDT, Lisandro Pezzi. A (re) produção de um espaço desigual: poder e segregação socioespacial em Guarapuava (PR). Dissertação (Mestrado em Geografia), Universidade Federal de Santa Catarina, Florianópolis, 2009

SCHMIDT, L. P.; LOBODA, C. R. A cidade enquanto um espaço desigual: o caso de Guarapuava. Caminhos de Geografia, Uberlândia, v. 12, n. 39, p. 21-30, set., 2011.

SCHNEIDER, S. A pluriatividade na agricultura familiar. Porto Alegre: UFRGS, 2003.

SCHNEIDER, S. Agricultura familiar e industrialização: pluriatividade e descentralização industrial no Rio Grande do Sul. Porto Alegre: UFRGS, 1999.

SEABRA, Odette C. de Lima. A muralha que cerca o mar: uma modalidade de uso do solo urbano. 122 f. Dissertação (Mestrado em Geografia) - Faculdade de Filosofia, Letras e Ciências Humanas, Universidade de São Paulo. São Paulo. 1979.

SENA, M. de F. A. de.; QUEIROZ, O. T. M. M. Impactos ambientais e sócio-culturais do turismo de segunda residência: O caso de Ponta da Tulha, Ilhéus, BA. Caderno Virtual de Turismo, vol. 6, n. 04, p. 94-106, 2006. Disponível em: <http://www.ivt.coppe.ufrj.br/caderno/ojs/include/getdoc.php?id=488\&article=162\&mo $\underline{\mathrm{de}=\mathrm{pdf}}>$. Acesso em 8 set. 2011.

SILVA, Gislene. O imaginário rural do leitor urbano: o sonho mítico da casa no campo. Tese (Doutorado em Ciências Sociais/Antropologia), Pontifícia Universidade Católica de São Paulo, 2000.

SILVA, José Borzachiello da. Fortaleza, a metrópole sertaneja do litoral. In: SILVA, J.B. Da; DANTAS, E.W.C.; ZANELLA, M.E.; MEIRELES, A.J.A. (Orgs.). Litoral e sertão: natureza e sociedade no nordeste brasileiro. Fortaleza: Expressão Gráfica, 2006, p. 45-55. 
SILVA, J.B. Da; DANTAS, E.W.C.; ZANELLA, M.E.; MEIRELES, A.J.A. (Orgs.). Litoral e sertão: natureza e sociedade no nordeste brasileiro. Fortaleza: Expressão Gráfica, 2006.

SILVA, Joseli M. Valorização fundiária e expansão urbana recente de GuarapuavaPR. Dissertação (Mestrado em Desenvolvimento Regional e Urbano) - Departamento de Geografia da Universidade Federal de Santa Catarina, Florianópolis, UFSC, 1995.

Processos Econômico-Sociais Regionais e seus Impactos sobre a Estrutura Urbana de Guarapuava-PR. Revista de História Regional, Guarapuava, v. 2, n.1, p. 942, $1997 . \quad$ Disponível em: <http://www.revistas2.uepg.br/index.php/rhr/article/viewFile/2024/ 1507>. Acesso 20 out. 2011.

SINGER, P. Economia política da urbanização. $14^{a}$. ed.Contexto: São Paulo, 1998.

SOUZA, M.; ALMEIDA, J. A. Multifuncionalidade dos espaços rural e urbano: reflexões iniciais. In: VELA, Hugo (Org.). Agricultura familiar e desenvolvimento sustentável no MERCOSUL.Santa Maria (RS): UFSM, 2003.

SOUZA, Mariângela Alice Pieruccini; CORRÊA, Walquíria Krüger. Produtores rurais, atividades não-agrícolas e trabalho pluriativo no município de cascavel-pr: uma discussão sobre a ruralidade e o território. $4^{\circ}$ ENCONTRO NACIONAL DE GRUPOS DE PESQUISA - ENGRUP. Anais... São Paulo, ENGRUP, 2008. p. 656-684.

SPOSITO, Eliseu Savério. Geografia e Filosofia: contribuição para o ensino do pensamento geográfico. São Paulo: Editora UNESP, 2004.

TULIK, Olga. Residências Secundárias: presença, dimensão e expressividade do fenômeno no Estado de São Paulo. Tese (Livre-docência) - Ciências Sociais Aplicadas, Universidade de São Paulo, São Paulo, 1995.

2001.

Turismo e Meios de Hospedagem: casa de temporada. São Paulo: Roca,

VEIGA, J. E. O Desenvolvimento Agrícola: uma visão histórica. São Paulo: Editora da USP/Hucitec, 1991.

A face rural do desenvolvimento: natureza, território e agricultura. Editora da UFRGS, Porto Alegre, RS. 2000.

O Brasil Rural precisa de uma Estratégia de Desenvolvimento. Núcleo de Estudos Agrários e de Desenvolvimento Rural. Ministério do Desenvolvimento Agrário, 2001

Cidades imaginárias: o Brasil é menos urbano do que se calcula. Campinas: Autores Associados, 2003.

Geo UERJ - Ano 15, nº. 24, v. 2, $2^{\circ}$ semestre de 2013

ISSN: 1415-7543E-ISSN: 1981-9021

http://www.e-publicacoes.uerj.br/index.php/geouerj 
Destinos da ruralidade no processo de globalização. Estudos Avançados, São Paulo, n.51, p. 51-67, maio/ago., 2004.

WAICHMAN, P. Tempo Livre e Recreação: um desafio pedagógico. Campinas: Papirus, 2001.

WANDERLEY, M. N. B. A emergência de uma nova ruralidade nas sociedades modernas avançadas o "rural" como espaço singular e ator coletivo. Estudos Sociedade e Agricultura, Recife, UFPE, v. 15, p. 87-145, mar., 2000.

Territorialidade e ruralidade no Nordeste: por um pacto social pelo desenvolvimento rural. In: SABOURIN, E; TEIXEIRA, O. A. (Eds) Planejamento e desenvolvimento dos territórios rurais: conflitos, controvérsias e experiências. Brasília: Embrapa Informação Tecnológica, 2002. p. 39-52.

WANDSCHEER, E. A. R. Residências Secundárias: manifestações e dinâmicas dos fluxos de visitantes no espaço rural (estudo nos municípios de Itaara e Restinga Seca). Santa Maria: FACOS - UFSM, 2009.

WANDSCHEER, Elvis Albert Robe; LINDNER, Michele; SOUZA, Marcelino de. Residências secundárias e o espaço rural: manifestações e dinâmicas na sociedade contemporânea. Revista Espaço Geográfico em Análise, Curitiba, 23, p. 32-64, 2011. Disponível em <http:// www.geografia.ufpr.br/raega> . Acesso em: 16 jun. 2011.

WANDSCHEER, E. A. R; e SOUZA, M. de. Residência secundária e o espaço rural: concepções dos impactos do fenômeno em distintos territórios turísticos. In: XIX ENGA. Anais... São Paulo, ENGA, 2009. p.1-15.

ZAMBERLAM, Jurandir; FRONCHETI, Alceu. Agricultura ecológica: preservação do pequeno agricultor e do meio ambiente. Petrópolis: Vozes, 2001.

Artigo recebido para publicação em maio de 2013.

Artigo aceito para publicação em julho de 2013.

Geo UERJ - Ano 15, nº. 24, v. 2, $2^{\circ}$ semestre de 2013

ISSN: 1415-7543E-ISSN: 1981-9021

http://www.e-publicacoes.uerj.br/index.php/geouerj 